\title{
THE NATURE OF FIBROSITIS AND THE INFLUENCE OF PSYCHOLOGICAL STATES UPON IT
}

\author{
By R. G. GORDON
}

Fibrositis is one of the commonest ailments with which the human race is scourged; at least that would seem to be the opinion of British physicians. It is not long since, however, that American physicians denied its existence, though they are nowadays more sympathetic to its recognition. It is interesting to examine the admirable surveys of rheumatic literature compiled by Dr. Hench and his collaborators and notice the growth of recognition and attention paid to fibrositis. The Americans took up the attitude that since there was no cut-and-dried pathology of fibrositis it should not be accorded the dignity of a " disease." In this complaint of lack of defined pathological lesions they have been justified, though Slocumb (1936) has recently described stages in the pathology of this disease-(1) a low-grade inflammatory sero-fibrinous exudate with proliferation of fibroblasts and bloodvessels, (2) local tissue thickenings with the formation of gross subcutaneous nodules, and (3) fibrous contractures or capsular thickenings.

The first person to describe any pathological lesions was Stockman (1920), who succeeded in dissecting out some nodules, and since his work was published British observers have generally regarded the nodule as the hall-mark of fibrositis. Hench (1935) considers that " nodules are the signposts of the disease and may or may not be tender, depending on the stage of the inflammatory activity therein. . . . In my experience biopsy often has been disappointing, and sections of tender muscular spots have often presented little or no histological abnormality and have given negative cultures."

All those who are experienced in the clinical examination of " rheumatic" patients will agree that at least in chronic cases nodules can be discovered if the patient's muscles are sufficiently relaxed and patience is exercised in deep palpation; but all 
nodules are not tender, nor do they all have a constant relation to the location of the subjective pains described by the patients. Nevertheless, May (1936) is probably correct when he says that " nodules are always evidence of a previous attack of sometimes subsymptomatic fibrositis. Even the non-tender ones are potentially troublesome." On the other hand, especially in acute fibrositis, if we are honest we must confess that it is not always possible to find palpable nodules in areas in which the patient complains of the most intense pain; the most we can say is that as our finger approaches the tender spot there is a local contraction of muscular fibres, and in such cases biopsy, as Hench says, is often entirely negative.

No doubt the explanation of this in some cases is that the pain complained of is really referred, and the true source of the pain is in one or more of the "spots " which have been described by Kellgren (1938) whence pain is referred to certain areas which he has determined. Nevertheless even Kellgren's " spots" are not always the seat of palpable nodules which can be dissected out.

It would appear, then, that the nodule is the hall-mark of $\vec{\varphi}$ the fibrositic subject, but the tombstone of the fibrositic attack although without doubt a fresh attack may occur in or about the tombstone.

Dr. Hench has very properly described the efforts of the present author (Gordon, 1936) to discuss the nature of fibrositis as pure speculation supported by no shred of pathological evidence. If, however, there is no demonstrable pathology of acute fibrositis either by biopsy or necropsy, then, if the condition exists which all those of us, even American rheumatologists, who have experienced an acute attack of fibrositis in our own vile bodies will vehemently proclaim, its nature can be arrived at only by critical consideration of the relative probabilities of speculative theories. I propose, then, without shame or apology, to devote the rest of this paper to speculations on the nature of acute fibrositis, in the hope that critical consideration may be given to them by others.

The acute attack of fibrositis is characterised by intense pain $N$ apparently induced by (1) sudden strain, (2) wear and tear, (3) chill, or (4) worry, or some combinations of these.

The pain of acute fibrositis is difficult to describe but is, as Sir Thomas Lewis (1938) has said, of the same nature as visceral 
pain. So much is this so that acute fibrositis is often diagnosed as thoracic or abdominal visceral disease-angina, pleurisy, colic, or appendicitis; and remedies, whether medical or surgical, are exhibited, the failure of whose action may be the first indication of the true nature of the disability. Lewis considers that muscular pain, being of the deep structure variety, is conveyed to a different area of the sensorium from skin pain. Such pains are often associated, as are for the most part those from the viscera, with quiescence, with slowing of the pulse, a fall of blood pressure, and nausea, the last phenomenon being responsible for the common designation "sickening" which is applied to these, but never to cutaneous pain. This sickening pain is not closely localised, and while, of course, due to stimulation of afferent nerves, the sensation produced is not comparable to that associated with the pioking out of pain spots on the skin. Deep pain would seem to be commonly if not exclusively due either to muscular spasm or to expansion within a closed space. That fibrositic pain is often due to muscular spasm is probable, for if the pain is not too acute localised hardenings can be felt which are mistaken for the permanent nodules of chronic fibrositis; but the former frequently disappear and cannot be rediscovered. In addition to this, however, the pain is sometimes wholly, or in some degree, due to dilatation of vessels and exudation of serum into the tissues, for sometimes no " nodule" temporary or permanent can be found, but instead a diffuse swelling; and Slocumb (1936) describes the first stage of fibrositis as a "low-grade inflammatory serofibrinous exudate." It is notable, too, as Burt (1936) has pointed out, that muscles which act in an enclosed space between bony surfaces are specially liable to fibrositis.

A good deal of attention has again been paid in recent months to the efficacy of injections of cocaine derivatives and of quinine in the treatment of fibrositis. This is, of course, nothing new, and the fact that this method of treatment is rediscovered every few years shows that its curative value as opposed to its relieving value is not so great as its enthusiastic advocates would wish their readers to believe. That such injections do relieve acute fibrositis, however, there is no doubt. The chief use of cocaine in medicine is for its action on the superficial pain component which Lewis (1936) has shown is different from the deep component, and its effect on the deep pain may be as much due to its inhibition of general muscular contraction and to its effect in contracting 
the arterioles as to any action on specific deep pain nerve endings if such exist. Similarly the local action of quinine (Cushny, 1910) is to inhibit exudation of serum and migration of leucocytesthat is, to diminish swelling in an enclosed space. If such injections, therefore, have anything but a transitory effect it must be because acute fibrositis does not have any permanent pathology, and is a reversible functional condition, which, however, like other functional conditions, may eventually lead to disease processes of more lasting duration which are at least to some extent irreversible, and in the case of fibrositis characterised by the nodule.

It is next necessary to consider the probable action of the four factors which are generally listed as being responsible for fibrositis in producing symptoms.

(i) Sudden strain or acute trauma may result in fibrositis, and in such cases the pathology is reasonably clear. A sudden strain may produce a rupture of muscle fibre with necessarily a small hæmorrhage. Such a rupture is most likely to happen when an unexpected involuntary movement caused by a slip, a stumble or a push causes a sudden stretching of a muscle already contracted. Such an accident causes acute deep pain mostly due to the expansion resulting from the bleeding and increaseo of pressure in an enclosed space. Later the clot formed may or may not be completely absorbed, in accordance with the vascularity of the tissue into which the hæmorrhage took place. If it took place in fascia or fibrous tissue power of absorption is not great. In such relatively avascular tissue the clot will become fibrosed by the growth of fibroblasts into it and so it will form a nodule. The same process may occur rather less acutely as the result of more gross trauma, which accounts for the fibrositis which tends to develop in the neighbourhood of fractures or dislocations or, for example, in the dorsal tissues of miners who have received deep bruising as a result of a fall of coal on their backs.

The nodule or plaque once formed is apt to be a focus of irritation, and with other " co-operative" causal factors-such as, e.g., chill-a new acute attack of fibrositis may be experienced in its locality, or it may be the seat of the more or less continuous ache of chronic fibrositis.

(ii) The next pathogenic factor is wear and tear, and this is the commonest of all, for fibrositis is most often found in the 
middle-aged and in those areas of the body which have been most subjected to strain - the shoulders of miners, the lumbar region of gardeners, and so on. Elsewhere (Gordon, 1936) I have suggested that in such cases the fibrositis is started by the deposition of the products of muscular metabolism which are not removed by the failing circulation of elderly and often hypothyroidic persons. This theory has been criticised because it has not been possible to produce the metabolites out of the nodule by biopsy or necropsy. Yet it is well proved that metabolic waste products are formed as the result of muscular activity and are normally removed by the circulation, and that circulation and elimination in the elderly and hypothyroidic are notoriously slow and inefficient. It has also been said that there is no justification for regarding these elderly sufferers from fibrositis as being hypothyroidic without a long series of controlled observations on their basal metabolism; but it is suggested that even without submitting the patient to the undoubted discomfort of metabolic estimation the clinician may recognise the overweight, lethargic, fibrositic with falling hair, dry cold skin which never sweats as being deficient in thyroid secretion. In such cases, then, we have a non-microbic focus of irritation with reactive congestion round it, with dilatation of vessels, exudation of serum going through the three stages described by Slocumb till the fully formed nodule is discoverable which calls for treatment by heat and massage. In the early congestive stage the condition may be relieved by injection of cocaine or quinine, or again when the deposit of new irritative material in the neighbourhood of old nodules results in an acute exacerbation similar relief may be experienced, but in such patients it is not my experience that anything like a permanent cure results from such methods or indeed from any method, though heat and massage will give longer remissions than any other form of treatment. The influence of the microbic theory of disease and the cult of focal infection is still so strong that in all probability it would be regarded by many as the rankest heresy to suggest that infection, and especially focal infection, is not a potent cause of fibrositis, and it would be absurd to suggest that it never is so. It is as difficult to prove as to disprove any theory of the cause of fibrositis, but to the disappointment of the focal infection fanatics it is seldom if ever possible to recover micro-organisms from fibrositic lesions, nor does the removal of septic foci always, 
or I would maintain even often, make any appreciable difference to fibrositis. Immediate relief is not unusual, but anything like a permanent cure from removal of such foci is definitely unusual. This immediate relief is not necessarily due to direct effect on the nodule or local condition, but may be due to effect on general circulation or even on the sensorium in the same way that protein shock and allied methods, such as some forms of vaccine therapy, may act. The real difficulty, of course, is that the majority of elderly people suffer from some degree of fibrositis, and it is seldom difficult to find some sort of focal infection in such people; but the juxtaposition of these conditions does nothing to prove cause and effect.

(iii) The next supposed cause of fibrositis is chill, but no one has explained why sitting in a draught should be followed by an acute stiff neck or a sudden onset of lumbago; but however much the scientist may protest that it can't happen because there is no demonstrable pathology, the answer of the unfortunate subject would probably resemble the comment of Dr. Johnson on Bishop Berkeley. Any explanation must be highly speculative, and therefore no apology is made for the following phantasy. It is assumed that chill and chill only is productive of the disability, and this does seem to be the clinical story in the case of certain susceptible people. It is interesting to note that there is a? definite analogy in another common malady-namely, chilblains. Chilblains occur in certain susceptible persons with poor distal circulation on exposure to cold, and manifest themselves as relatively small circumscribed areas of skin and subcutaneous tissue, which are the seat of vascular dilatation and exudation of serum, which is accompanied by the normal type of unpleasant cutaneous sensation-namely, itching and sharp pain.

The only possible explanation of the chilblain is that in certain people who may be susceptible by reason of vitamin deficiency, endocrine anomaly, or other unknown cause, there are "loci minoris resistantiæ " in the peripheral part of their vascular network which under the influence of cold are the seat of dilatation and serum exudation.

When considering the effect of chill in relation to fibrositis we may notice certain facts. It is not everyone who sits in a draught who gets an acute stiff neck or an acute lumbago, therefore we are dealing with susceptible persons. The clinical symptoms and signs consist of the deep form of unpleasant sensation-viz., 
indescribable "sickening" pain (vide Lewis, 1938) which tends to radiate and be referred in certain directions (vide Kellgren, 1938) and local areas of tenderness and perhaps slight palpable swelling. If any pathology exists at all it consists of dilatation of vessels and exudation of serum (Slocumb, 1936).

Have we then in such cases a condition occurring in deep fascial layers and muscles analogous to the chilblain, the symptoms being translated, as might be expected, into terms of deep sensation as opposed to superficial sensation?

The whole question of "the susceptible person" and the " unstable vascular network" brings us to the discussion of the next commonly accepted cause of fibrositis-namely, "worry", since prolonged emotion is liable to disturb the autonomic control; but before discussing this it might be remarked that an interesting and fruitful line of enquiry is opened for those who have access to large numbers of patients. They might undertake to investigate whether there is any analogy between biochemical findings in those susceptible to chilblains and those susceptible to such fibrositic manifestations as acute stiff neck. The difficulty of course is that neither chilblains nor acute stiff neck is a sufficiently serious disability to warrant retention of many such patients in hospitals for periods long enough to carry out such investigations or to encourage such patients voluntarily to submit to the necessary laboratory discipline.

(iv) Fibrositis due to psychogenic causes will of course include those said to be due to "worry" in the ordinary category of ætiological factors.

Doubtless, as Halliday (1937) has pointed out, there are a number of patients who complain of fibrositic-like pains which are purely symbolic in nature as expressive of a state of mind, and are being consciously or unconsciously used by the patient as a protest against the situation in which he finds himself or as an escape from the obligations which are imposed upon him by circumstances. Since some degree of fibrositis is almost always discoverable in the form of nodules which may be "subsymptomatic ", it is a matter for argument whether the pain is entirely symbolic-i.e., originating exclusively in the sensorium-or whether the patient is using a mild degree of discomfort either consciously or unconsciously to achieve an object; but it should be stressed that the vast majority of such patients are not deliberate malingerers and are therefore acting unconsciously. 
For example, a chief petty officer complained of pain in the back. He was a perfect example of Halliday's type of case, for he had finished his twenty-five years' service and so was eligible for full pension. He had a sedentary job waiting for him in civil life which did not involve the strenuous physical exercise which was expected of him in the Navy and which he declared he could not do on account of his pain. He felt he had served the Navy well in all parts of the world, but did not enjoy the war or appreciate the constant attention of enemy bombers. On examination he certainly had some fibrositic nodules such as might be expected in any man of his age who had lived an active life, but they were very useful to him in achieving discharge from the Service, and the treatment of this man would obviously have to be directed to inspiring him with greater martial ardour rather than bothering very much about the nodules in his back.

The next group are those who complain of fibrositic pain not primarily because they are definitely using it for the purpose of avoiding a situation, but because their whole sensorium is more sensitive to incoming stimuli than normally is the case, and therefore the pain from a relatively mild fibrositis is more intensely felt. Such a case was a young soldier who had been subject to the most intense aerial bombardment and as the result of this was suffering from a severe degree of acute anxiety neurosis of the war service type. He stated that for some time he had been accustomed to suffer at times from "rheumatic" pains in his back, but had never given much heed to them and had never had to leave work on account of them. Since the bombardment, however, the pains in his back had become very intense, so much so that he could not be comfortable lying in bed because of them, and they contributed to his insomnia, which was, as usually is the case, a prominent symptom of his anxiety. Examination disclosed a few tender nodules in his lumbar and gluteal muscles. His anxiety was accompanied by a markedly increased sensitivity to sound, light, and touch, and treatment directed to his anxiety by abreaction and reassurance diminished this sensitivity with a corresponding diminution of his backache. If, however, the anxiety of such a patient is not completely removed he is apt to cling to his most obvious and as he perhaps hopes his most objective disability, the "rheumatism of his back," since in his mind this alone protects him from a future situation which must still be fraught with anxiety. This is the 
situation which so often prolongs disability in peace-time workmen's compensation cases, since they are faced with the two questions: Is there work for me if I am declared fit ? and if there is work, shall $I$ be able to continue to carry it on or shall $I$ in three months find myself given the sack with no prospect of re-employment? This makes it so essential that proper rehabilitation and guarantee of employment should be provided for such cases if they are to be got back to work.

The next group is much more difficult to define and much more difficult to treat successfully. I have dealt elsewhere (Gordon, 1940) with the influence of anxiety states on vascular and other vegetative function which will produce sensitivity to atmospheric conditions and vascular instability. Reference has been made to susceptible people who are especially prone to chill, and anyone who has large experience of persons suffering from so-called sciatica, which is most commonly due to a gluteal fibrositis, will realise how often the trouble is said to be due to cold, sitting on wet grass, etc., and how often the sciatic patient belongs to the class which includes all grades from those who are described as highly strung to those suffering from a frank anxiety neurosis. Sciatica is a very painful complaint, as all sufferers from it will agree, and is not as a rule quickly cured; but many people take much longer to get better than might be expected by the optimistic physician, and the reason is that a vicious circle is set up by the constant pain and lack of sleep which sensitises the sensorium so that the intensity of perception of pain is increased and with it the anxiety which may still further increase the fibrositic reaction by its influence on the vegetative controlling centres in or about the hypothalamus. Nor is this anxiety lessened by the enthusiasm with which consulting physicians and surgeons talk about sciatic neuritis and forcibly stretching the nerve, of sacro-iliac strain and elaborate manipulation, and subluxation of the nucleus pulposus and operations to remove these mysterious pressures, which any neurologist would expect to paralyse the nerve roots and thus abolish the pain. Probably after all the best treatment for these sciatic patients is masterly and sympathetic inactivity and skilful neglect of the physical side of the trouble combined with adequate attention to the mental side.

It is not, however, only in the gluteal region that the frigisensitive neurotic person is prone to fibrositis, and the more 
youthful type of fibrositic patient is often of this type as opposed to the more phlegmatic hypothyroidic elderly type whose fibrositis is associated with much more definite nodule formation. The pathology of this, as has been suggested, is the sequence of poor circulation and elimination with failure to deal with irritative metabolites. In the younger patient, on the other hand, it is much more difficult to discover well established nodules, and the attacks may be and generally are much more acute. It is suggested that in such patients circulation is irregular and uncertain and local spasms of arterioles or dilatation of capillaries are apt to occur, especially under the influence of cold or chill. On the other hand, in some cases, as Alkan (1930) has suggested in the case of smooth muscle, local muscular spasms may lead to anæmia, stasis, ischæmia and subsequent nodule formation. Either of such processes would result in muscular pain, and, as Lewis (1938) says, this is not a stimulating but a depressing pain, and depression, if it is not a true psychotic depression, increases perception of pain. To such people pain is always a source of alarm and anxiety and links up with unconscious fears and selfaccusations, associated with feelings of guilt calling for punishment and so a vicious circle is established in which the incoming paing sensations intensify the already existing or potential anxietyô. state, while the anxiety state may well by its disturbance of endocrine and hypothalamic activity still further increase the sensitivity and vascular instability which is the matrix of the fibrositis. Cases in which even conscious anxiety is expressed by an attack of acute fibrositic pain are by no means uncommon, and the muscular pains which are met with in those who have to nurse a beloved relative through a serious illness are not all due to the standing and bending involved. The pain in such cases may become hysterical and be used to avoid the painful situation, but this is by no means always the case, for many such patients emphatically do not avoid the situation.

It may be observed, then, that psychogenic factors may be responsible for a fibrositic type of pain and may intensify or even produce an acute fibrositis which may develop into a chronic and partially irreversible condition with typical nodule formation. It is suggested that it is extremely unlikely that any one specific cause will be found to be responsible for a "disease " fibrositis, and that what we call for convenience fibrositis is by no means always inflammatory as is suggested by the suffix "itis," but is 
a tissue reaction to a number of pathogenic causes. The nature of the particular pathogenic agent should be considered in each individual case, since only so can appropriate treatment be indicated, and amongst these agents disturbances of the psyche, acting either independently or in conjunction with disturbances of the soma, must not be neglected.

\section{SUMMARY}

Although fibrositis is so common it is still poorly understood. This is because it is so difficult to define an established pathology, chiefly since, at least in the acute form, there is no demonstrable pathology and the nodule is often the tombstone of a previous attack rather than the hall-mark of a present attack.

An exposition of the nature of fibrositis must therefore be largely speculative, and it is suggested that four commonly listed causes of fibrositis-sudden strain, wear and tear, chill, and worry -may represent four different pathological processes. The sequences may be:

Sudden strain-hæmorrhage-organisation of clot-nodule formation.

Wear and tear-deposition of metabolites-failure of removal and elimination-reactionary formation of nodules.

Chill-local vascular disturbances analogous to those of chilblain with or without permanent nodule formation.

Worry-psychogenic muscular pain or fibrositis of three sorts: (1) when pain is used as a symbol of emotional discontent, (2) when the whole sensorium is oversensitised as a result of acute emotional disturbance, (3) when chronic emotional disturbances produce endocrine and autonomic disturbances through vegetative controlling centres in the hypothalamic region which are followed by fibrositis.

The relation to these speculations of the nature of muscular pain and the effect of local analgesic injections is discussed, as is the failure of the microbic and focal infection theories to establish themselves as the universal cause of fibrositis.

\section{REFERENCES}

Alkan L.: "Anatomische Organkrankheiten aus seelischer Ursache." Hippokrates-Verlag, Stuttgart, 1930.

Burt, J. B.: Fifth International Congress on Rheumatism, Sweden, 1936. Report in Brit. Med. Journ., 1936, ii. 604. 
Cushny, A. R.: "A Textbook of Pharmacology and Therapuetics," 5th edit. London, 1910.

Gordon, R. G.: Brit. Med. Journ., 1936, ii. 1243-1246.

Gordon, R. G.: Edin. Med. Journ., 1940, xlvii. 16.

Halliday, J. L.: Brit. Med. Journ., 1937, i. 213-225.

Hench, P. S.: "Acute and Chronic Arthritis." Nelson Loose Leaf Surgery. London, 1936.

KellgRen, J. H.: Brit. Med. Journ., 1938, i. 324.

Lewis, Sir T.: Brit. Med. Journ., 1938, i. 321.

May, F.: Med. Journ. of Australia, 1936, ii. 447.

Slocumb, C. H.: Journ. Lab. and Clin. Med., 1936, xxii. 56.

Stockman, R.: "Rheumatism and Arthritis." Edinburgh, 1920. 